\title{
Bacillus mycoides: a bacterial pathogen of channel catfish
}

\author{
Andrew E. Goodwin, J. Spencer Roy, Jr, John M. Grizzle*, M. Terrell Goldsby, Jr \\ Department of Fisheries and Allied Aquacultures, Alabama Agricultural Experiment Station, Auburn University, Auburn,
} Alabama 36849, USA

\begin{abstract}
Bacillus mycoides was isolated from channel catfish Ictalurus punctatus during an epizootic in a commercial culture pond in Alabama, USA. During the epizootic, the fish had pale areas or ulcers on the dorsum and focal necrosis of epaxial muscle. Dissolved oxygen, ammonia, and other water characteristics were within normal ranges. Pathogens other than $B$. mycoides were not found in the moribund fish. Histologic examination of the lesions revealed necrotic muscle with chains of Grampositive bacilli. Intramuscular injection of $1.6 \times 10^{4}$ colony forming units of $B$. mycoides into channel catfish caused lesions that resembled those in fish during the epizootic. Similar lesions developed after subcutaneous injection of $B$. mycoides, but intraperitoneal injection or application of $B$. mycoides to abraded skin did not result in lesions.
\end{abstract}

\section{INTRODUCTION}

Bacillus mycoides is a Gram-positive spore-forming species of the family Bacillaceae (Claus \& Berkeley 1986). B. mycoides is ubiquitous in soils (Claus \& Berkeley 1986) and has been implicated in diseases of humans (Ansell et al. 1980) and of parrots Psittacus erithacus (Burr 1981). B. mycoides was classified as a species in 1886, reclassified as Bacillus cereus var. mycoides in 1946 (Gibson \& Gordon 1974) and then again reclassified as B. mycoides in 1986 (Claus \& Berkeley 1986). Although there are many older reports of toxin production and disease caused by $B$. cereus, little of that information can be clearly attributed to B. $m y$ coides. There have been no previous reports of $B$. mycoides as a fish pathogen.

The major bacterial pathogens of channel catfish Ictalurus punctatus are Gram negative and include species of Aeromonas, Cytophaga (Flexibacter), and Edwardsiella (Thune 1991, Jack et al. 1992). Reports of Gram-positive pathogens in channel catfish are rare and implicate species of Carnobacterium (Baya et al. 1991). There have been reports of Bacillus spp. as pathogens of fish other than channel catfish. An isolate

-Addressee for reprint requests identified as Bacillus cereus was found on necrotic gills of common carp Cyprinus carpio (Pychynski et al. 1981) where it could have been a saprophyte living on necrotic tissue. An isolate of $B$. cereus from apparently healthy striped bass Morone saxatilis was lethal to other striped bass when injected at $10^{7}$ bacteria per fish (Baya et al. 1992).

In this report, we describe an epizootic with high mortality that began in May 1992 in an earthen, 2.5 ha commercial channel catfish culture pond in Alabama, USA. At the beginning of the epizootic the pond contained 5000 channel catfish averaging $500 \mathrm{~g}$ each and another 70000 channel catfish averaging $40 \mathrm{~g}$ each. Over a $4 \mathrm{~d}$ period, feed consumption dropped by $65 \%$, and then on 27 May several dead or moribund fish were found with ulcerative skin lesions. During the morning of the same day, $0.75 \mathrm{mg} \mathrm{l}^{-1} \mathrm{CuSO}_{4}$ was added to the pond; this concentration is approximately $75 \%$ of the maximum safe concentration based on total alkalinity of $115 \mathrm{mg} \mathrm{l}^{-1}$ as $\mathrm{CaCO}_{3}$.

By the evening of 27 May there were numerous dead fish, and many fish were swimming slowly just beneath the surface near aerators and along the bank of the pond. Moribund fish were darker than normal except for pale areas on the dorsum. Muscle under the pale areas was opaque, and some fish had ulcerative 
lesions in the same region. Intestines contained some feed and gas and wore constricted at irregular intervals by contracted muscularis. Other viscera appeared normal except that blood vessels of the parietal peritoneum were congested. Minimal bleeding occurred when the fish were filleted or when the caudal peduncle was severed. The water temperature in the evening of 27 May was $26^{\circ} \mathrm{C}$, and water chemistry variables (dissolved oxygen, $\mathrm{pH}$, nitrite, chloride, ammonia, carbon dioxide, and total alkalinity) were within safe limits.

Starting on 30 May, fish were fed a ration containing Terramycin but continued to die at a decreasing rate until mid June when it was estimated that $80 \%$ of the $500 \mathrm{~g}$ fish and $10 \%$ of the $40 \mathrm{~g}$ fish had died. Green sunfish Lepomis cyanellus, threadfin shad Dorosoma petenense, and golden shiners Notemigonus crysoleucas living in the same pond did not die and showed no signs of distress.

Parasites, viruses, and water quality problems were ruled out as likely causes of the epizootic. Bacilli were noted in histological sections of muscle lesions and a single bacterial species was isolated from moribund fish. In this study, we identified the isolate as Bacillus mycoides and demonstrated that fish injected with this bacterium developed muscle lesions resembling those that occurred during the epizootic.

\section{MATERIALS AND METHODS}

Examination for pathogens. Five moribund channel catfish from the affected pond were necropsied on 27 May. Wet mounts of the skin and gills were examined for protozoans, fungi, and bacteria. The liver, trunk kidney, and brain were inoculated on blood agar $(5 \%$ sheep blood in blood agar base; Difco, Detroit, MI, USA). Samples of the liver, trunk kidney, spleen, gills, muscle, and skin were fixed in Bouin's fluid for histological evaluation. Paraffin sections were stained with hematoxylin and eosin (H\&E), Periodic acid-Schiff (PAS), and Brown and Hopps stain (Clark 1981).

On 4 June, 4 additional fish with skin lesions were necropsied as above except that necrotic muscle, located under intact skin, was aseptically dissected and placed on Müller-Hinton ( $\mathrm{MH})$, brain-heart infusion (BHI), and cornmeal agars (Difco). Identification of the bacterium was performed as described by Parry et al. (1983), Harmon (1982), Claus \& Berkeley (1986), and Sneath (1986). Confirmation of the identification was done by gas chromatographic fatty acid analysis using the Microbial Identification System (Sherlock Version 3.7. Microbial ID, Inc., Newark, DE, USA) according to Kloepper et al. (1992). Antibiotic sensitivity was tested using paper discs on MH agar (Phillips 1991).
Pathogenicity studies. Bacillus mycoides isolated from infected channel catfish during the epizootic were subcultured once on $\mathrm{BHI}$ agar before use in pathogenicity studies. Bacterial suspensions were prepared by vortexing $B$. mycoides colonies in saline followed by $2 \mathrm{~min}$ in a hydrosonic cleaner $(22 \mathrm{~W}, 50 \mathrm{kHz})$ to separate $B$. mycoides chains into individual bacilli (separation verified microscopically). The concentration of B. mycoides in the stock suspension was determined by plating serial dilutions.

In a preliminary study to determine an appropriate route of administration, 2 channel catfish, 16 to $18 \mathrm{~cm}$ in total length, were placed in each of four $40 \mathrm{l}$ aquaria containing dechlorinated municipal water. Temperature was maintained at $26^{\circ} \mathrm{C}$ with aquarium heaters, and each aquarium had an airlift filter containing charcoal and glass fiber. Fish from one tank were used for each of the following treatments: (1) intraperitoneal (ip) injection of Bacillus mycoides suspended in $0.2 \mathrm{ml}$ saline (concentration of bacteria used in this preliminary experiment was not determined), (2) intramuscular injection (im) in the epaxial muscle with $0.1 \mathrm{ml}$ of the same suspension, (3) subcutaneous (5c) injection in the same region with $0.1 \mathrm{mI}$ of the same suspension, and (4) application of $B$. mycoides to cutaneous abrasions. For this last treatment 5 to $7 \mathrm{~cm}^{2}$ of the epidermis were removed from the dorsolateral surface of the fish with coarse sandpaper, and the wound was rubbed with a cotton swab dipped in the $B$. mycoides suspension. The fish were necropsied when lesions became apparent, and all remaining fish were necropsied on the fifth day. Samples of muscle, liver, spleen, and trunk kidney from each fish were cultured on $\mathrm{MH}$ agar, and tissues from the sc- and im-injected fish were fixed in Bouin's solution for histological evaluation.

In an additional preliminary experiment, channel catfish, 20 to $25 \mathrm{~cm}$ in total length, were obtained from a group that was inadvertently confined without aeration. After $3 \mathrm{~h}$ about $80 \%$ of the fish were dead. Oxygen was bubbled through the water for $10 \mathrm{~min}$, and the survivors removed to aquaria. Six fish were placed in each of 5 aquaria containing dechlorinated municipal water and maintained at $25^{\circ} \mathrm{C}$. Aquaria had charcoal and glass-fiber filters, and $50 \%$ of the water in each tank was replaced daily. As they were placed in aquaria, the fish were injected in the epaxial muscle with $0,130,1300,13000$, or 130000 colony forming units (CFU) of Bacillus mycoides in $0.1 \mathrm{ml}$ of $0.9 \%$ $\mathrm{NaCl}$ solution. The fish were necropsied when skin lesions developed, and fish without lesions were observed for $7 \mathrm{~d}$. Samples of the muscle underlying skin lesions were cultured on $\mathrm{MH}$ agar. Bacteria isolated (other than B. mycoides) were identified using API tests (API Analytab, Inc., Plainview, NY, USA). 
The infectious dose of Bacillus mycoides in healthy channel catfish was determined by placing 6 channel catfish, $10 \mathrm{~cm}$ in total length, in each of four $40 \mathrm{l}$

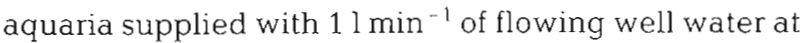
$25^{\circ} \mathrm{C}$. Two days after the fish were placed in the aquaria (5 d before they were injected with $B$. mycoides) they were given a $24 \mathrm{~h}$ static bath treatment of $4 \mathrm{mg} \mathrm{l}^{-1}$ enrofloxacin (Baytrol, Miles Laboratories) and $0.5 \% \mathrm{NaCl}$. Enrofloxacin was used to reduce the chance that other pathogens or saprophytes would invade the $B$. mycoides lesions (as they did in the experiment with fish subjected to hypoxia) and complicate identification of $B$. mycoides as a primary pathogen. Fish in each tank were injected in the epaxial muscle with $0,160,1600$, or 16000 CFU of B. mycoides in a volume of $10 \mu l$. Fish were removed from the aquaria when lesions became apparent, and blocks of tissue from the lesions were placed on $\mathrm{MH}$ agar. Fish without lesions were observed for $14 \mathrm{~d}$.

\section{RESULTS}

\section{Examination of fish from the epizootic}

During the initial necropsies on 27 May, wet mounts revealed no bacteria or fungi and few parasites. Fish were not tested for viruses because only one virus, channel catfish virus (CCV), is known to cause epizootics in channel catfish and the lesions seen during this epizootic were not typical of CCV. In addition, CCV almost always affects fish younger than those killed during this epizootic. Sections of muscle lesions had necrotic areas containing long chains of Gram-positive, PAS-negative organisms and few inflammatory cells (Fig. 1). Sections of gills and internal organs were normal except for one fish that had a focus of granulomatous exudate in the liver. Bacteria were not isolated from the liver, trunk kidney, and brain. Isolation of bacteria was not attempted from muscle

Muscle explants underlying unbroken but pale skin were cultured from 4 channel catfish on 4 June, and a single bacterial species was isolated from all 4 fish. Histologically, the internal organs, skin, and gills of these fish were normal. Sections of necrotic muscle lesions contained Gram-positive bacilli that resembled those of fish sampled on 27 May.

\section{Identification of Bacillus mycoides}

The bacteria isolated on 4 June produced raised rhizoid colonies with a counterclockwise filamentous swirling pattern (Fig. 2). Biochemical and morphological characteristics 1 to 7 in Table 1 identified the isolate as a member of the genus Bacillus (Sneath 1986). Characteristics 8 to 13 narrowed the identification to the 4 species shown in Table 1 (Claus \& Berkeley 1986). According to Parry et al. (1983), characteristics $2,3,4,5,8,14$, and 15 identified the isolate as one or the other of the 4 species in Table 1 . Tests 16 to 19 eliminated B. anthracis (Harmon 1982, Parry et al. 1983). B. thuringiensis was eliminated because our isolate did not form parasporal crystals, and $B$. cereus was eliminated based on motility, growth at $45^{\circ} \mathrm{C}$, and colony morphology (Harmon 1982, Parry et al. 1983). The characteristics of our isolate were identical to those of B. mycoides. Fatty acid analysis (data not shown) confirmed that the isolate was $B$. mycoides GC subgroup A. Our B. mycoides isolate was susceptible to nalidixic acid, oxytetracycline, nitrofurazone, erythromycin, and novobiocin, and was resistant to Romet (orthometoprim plus sulfadimethoxine).

\section{Pathogenicity studies}

Fish that received $\mathrm{sc}$ and im injections developed a light-colored area over the injection site within $24 \mathrm{~h}$, and the underlying muscle became necrotic. Fish injected ip did not develop external lesions prior to necropsy on the fifth day postinjection even though they received twice as many bacteria. Fish that were abraded healed within $5 \mathrm{~d}$ and did not develop Bacillus mycoides infections (Table 2). B. mycoides was reisolated from the muscle, liver, and trunk kidney of all fish except those from the abraded-skin treatment. Histologically, muscle lesions from fish that were injected im or sc with $B$. mycoides suspensions resembled lesions of fish from the epizootic and contained numerous Gram-positive bacilli. Based on this preliminary study, im injection was chosen as the route of administration for subsequent experiments.

After exposure to hypoxic conditions, fish injected with Bacillus mycoides and control fish developed ulcerated skin lesions from which Aeromonas hydrophila complex was isolated. B. mycoides was reisolated from 10 of the 14 muscle lesions that were cultured from injected fish, including 1 fish injected with 130 B. mycoides and 3 fish injected with 1300 B. mycoides (Table 2). $B$. mycoides was not isolated from the control fish.

Fish treated with enrofloxacin and then injected im with $1.6 \times 10^{4} \mathrm{CFU}$ of Bacillus mycoides $5 \mathrm{~d}$ after enrofloxacin treatment developed light-colored areas around the injection site within $24 \mathrm{~h}$ of injection. After $48 \mathrm{~h}$, ulcerative lesions had developed at the injection site (Fig. 3), and B. mycoides was isolated from the muscle of 5 of 6 fish (Table 2). No other bacteria were isolated from these fish. None of the fish with lesions developed obvious behavioral changes, reduced 


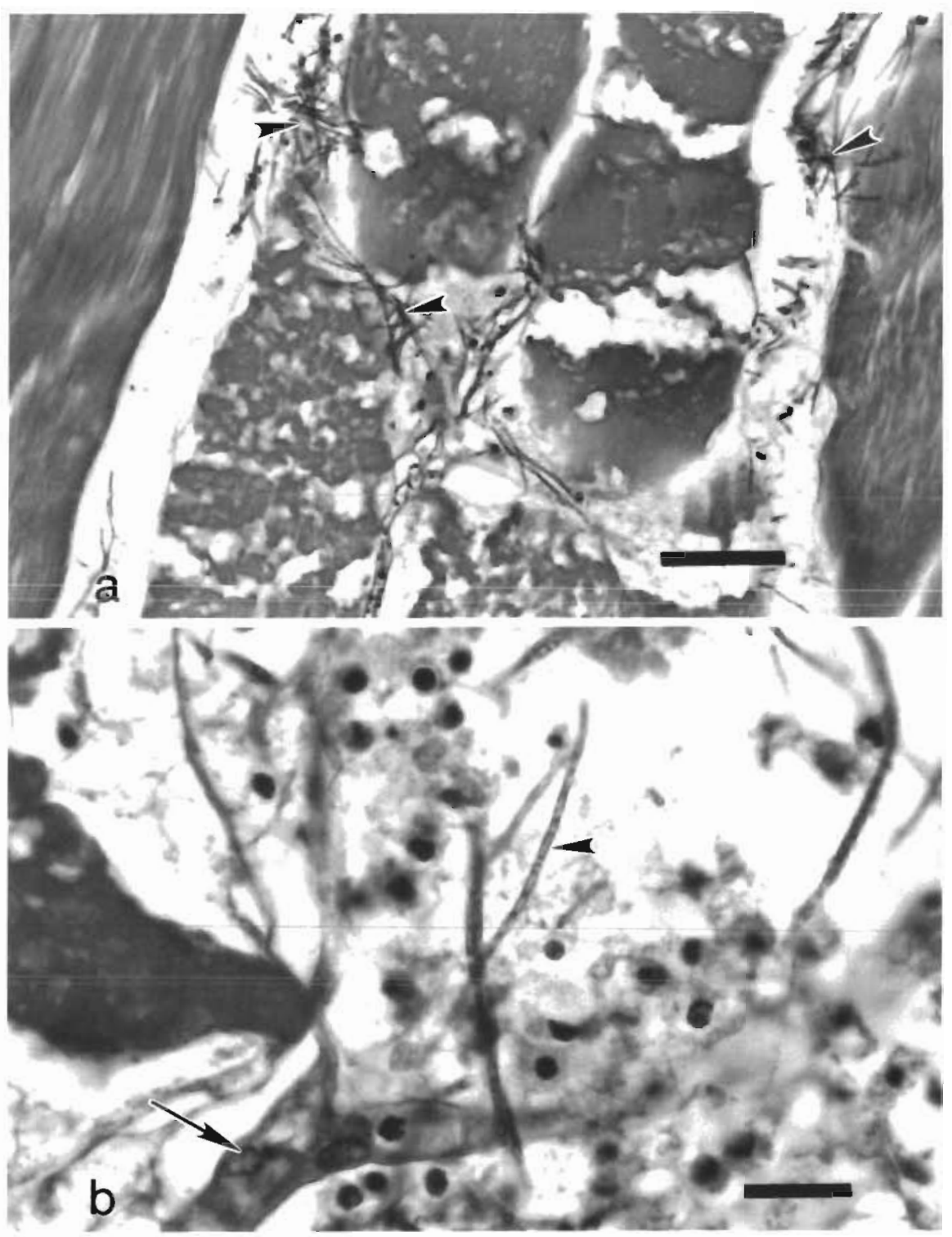

Fig. 1. Ictalurus punctatus. Muscle lesions from a moribund fish captured during an epizootic caused by Bacillus mycoides. H\&E. (a) Chains of B. mycoides (arrowheads) within necrotic muscle: scale bar $=25 \mu \mathrm{m}$. (b) Necrotic muscle with $B$. mycoides chains (arrowhead), remnants of sarcolemma (arrow), and scattered necrotic erythrocytes; scale bar $=50 \mu \mathrm{m}$

bleeding, or peritoneal congestion resembling abnormalities of fish from the epizootic. All of the lower doses of B. mycoides failed to cause lesions within $14 \mathrm{~d}$, at which time the experiment was terminated.

\section{DISCUSSION}

Histologically, necrotic muscle lesions of moribund fish collected during the epizootic contained Grampositive organisms and resembled lesions of mice experimentally infected with Bacillus cereus (Burdon et al. 1967). B. mycoides was the only bacterium isolated from fish during the epizootic $i$ water quality problems were found. Injection of the $B$. mycoides isolate into channel catfish produced lesions that resembled lesions of fish examined during the epizootic. B. mycoides was reisolated from the lesions of fish injected with $B$. mycoides. The similarity of lesions and reisolation of the same pathogen from lesions of experimentally infected fish provided convincing evidence that $B$. mycoides was the cause of the epizootic reported on here.

The lack of behavioral changes, bleeding, and peritoneal congestion in experimentally infected fish may have been due to several factors. Our experimental 


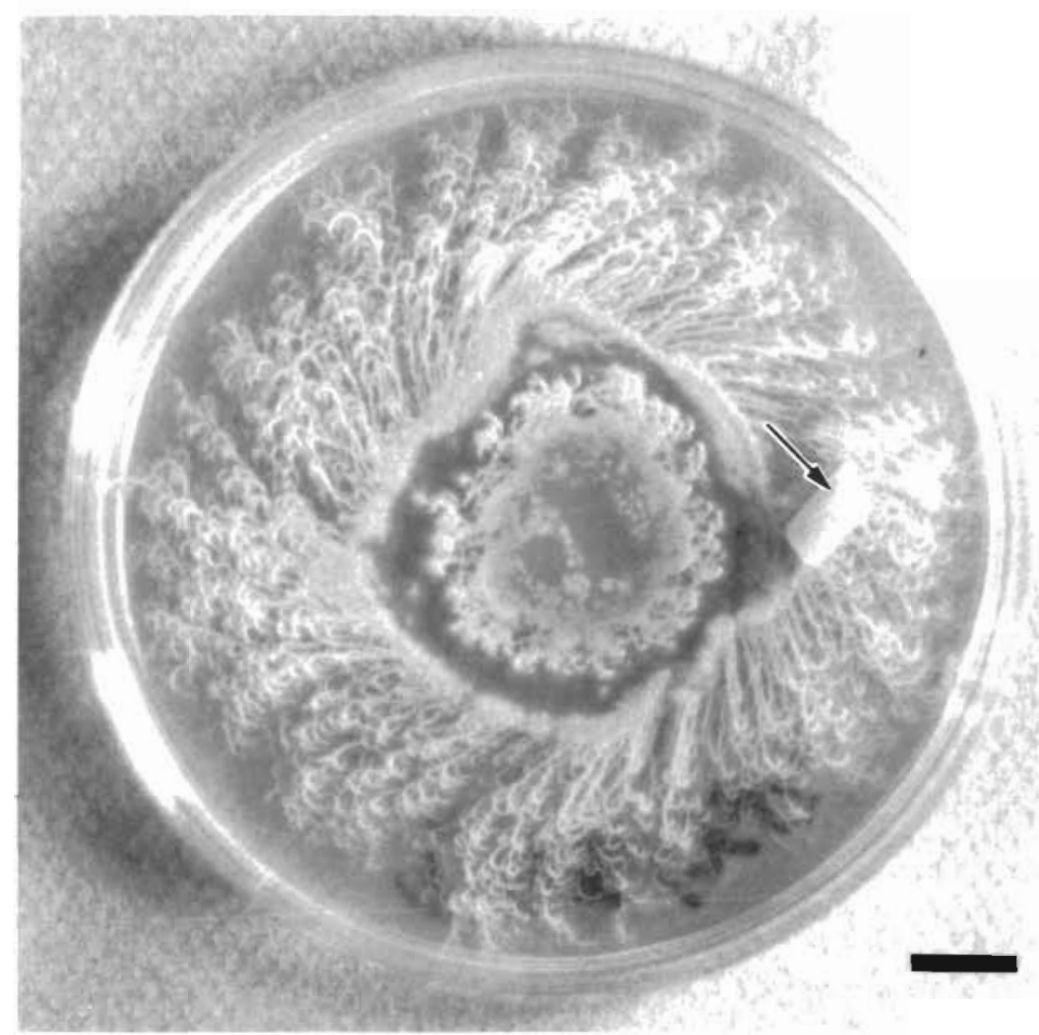

Fig. 2. A 48 h culture (incubated at $28^{\circ} \mathrm{C}$ ) of Bacillus mycoides isolated from Ictalurus punctatus. The colony was subcultured on Müller-Hinton agar from an agar block (arrow) that rolled toward the edge of the plate after the colony was established. Scale bar $=1 \mathrm{~cm}$

fish used in determining infectious dose were much smaller than those involved in the epizootic, and reduced bleeding and peritoneal congestion are more difficult to observe in small fish. Fish behavior would also be expected to be different in aquaria. Alternatively, subculture of the Bacillus mycoides or differences in the environment or physiological status of the fish could have changed the pattern of exotoxin pro- duction by the bacteria. It has been reported that culture conditions influence exotoxin production by B. cereus (Burdon et al. 1967, Gilbert \& Kramer 1984). It has also been shown that $B$. cereus produces toxins that cause disseminated intravascular coagulation (Bonventre \& Eckert 1963, Burdon et al. 1967), a possible explanation for the congestion and lack of bleeding seen in fish during the epizootic.

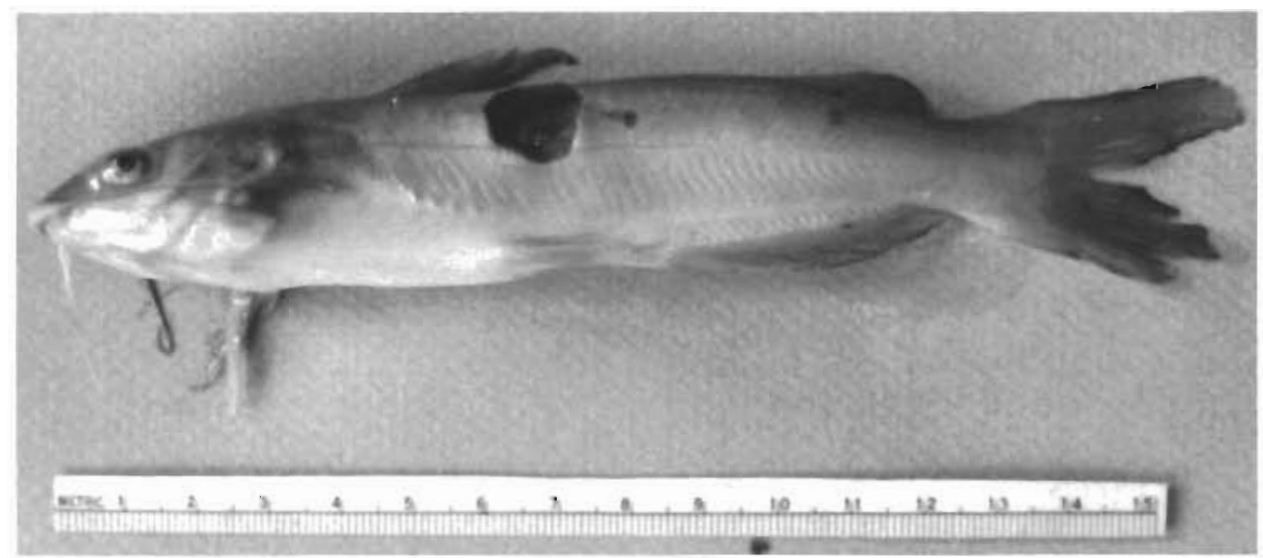

Fig. 3. Ictalurus punctatus. Necrotic muscle lesion at the site where $1.6 \times 10^{4}$ Bacillus mycoides colony forming units were injected intramuscularly 
Table 1. Characteristics of a bacterial isolate from Ictalurus punctatus. Information about Bacillus species is from Harmon (1982). Parry et al. (1983), Claus \& Berkeley (1986), and Sneath (1986)

\begin{tabular}{|c|c|c|c|c|c|}
\hline Characteristics & Isolate & B. mycoides & B. cereus & B. thuringiensis & $B$ anthracis \\
\hline 1. Endospore formed & + & + & + & + & + \\
\hline 2. Rod shaped & + & t & + & + & + \\
\hline 3. Strict anaerobe & - & - & - & - & - \\
\hline 4. Catalase & + & + & + & + & + \\
\hline 5. Gram stain & + & + & + & + & + \\
\hline 6. Cell diameter $<2.5 \mu \mathrm{m}$ & + & + & + & + & + \\
\hline 7. Acid from D-glucose & + & + & + & + & + \\
\hline 8. Voges-Proskauer (V-P) & + & + & + & + & + \\
\hline 9. $\mathrm{pH}$ in $\mathrm{V}-\mathrm{P}$ broth $<6$ & + & + & + & + & + \\
\hline 10. Indole & - & - & - & - & - \\
\hline 11. Hydrolize casein & + & + & + & + & + \\
\hline 12. Hydrolize gelatin & + & + & + & + & + \\
\hline 13. Cell diameter $>1 \mu \mathrm{m}$ & + & + & + & + & + \\
\hline 14. Spore oval & + & + & + & + & + \\
\hline 15. Lecithinase activity & + & + & + & + & + \\
\hline 16. Hemolytic & + & + & + & + & - \\
\hline 17. Penicillin resistance & + & + & + & + & - \\
\hline 18. Colony tenacity & - & - & - & - & + \\
\hline 19. Tyrosine hydrolized & + & $+/-$ & + & + & - \\
\hline 20. Parasporal crystals & - & - & - & + & - \\
\hline 21. Motility & - & - & + & + & - \\
\hline 22. Growth at $45^{\circ} \mathrm{C}$ & - & - & + & + & - \\
\hline 23. Rhizoid colony & + & + & - & - & - \\
\hline
\end{tabular}

Table 2. Ictalurus punctatus. Number of fish from which Bacillus mycoides was isolated following 3 separate challenge experiments. Many of the fish in Expt 2 had concomitant infections with Aeromonas hydrophila complex

$\begin{array}{lc}\text { Experimental }_{\text {variable }^{d}} & \text { Fish infected with } \\ \text { B. mycoides }\end{array}$

Expt 1: Variable routes of administration

$\begin{array}{ll}\text { im } & 2 / 2 \\ \mathrm{sc} & 2 / 2 \\ \text { ip } & 2 / 2 \\ \text { abr } & 0 / 2\end{array}$

Expt 2: Variable dose (CFU fish $\left.{ }^{-1} ; \mathrm{im}\right)$ in hypoxic fish

$\begin{array}{rr}0 & 0 / 6 \\ 130 & 1 / 6 \\ 1300 & 3 / 6 \\ 13000 & 2 / 6 \\ 130000 & 4 / 6\end{array}$

Expt. 3: Variable dose (CFU fish ${ }^{-1}$ im) in healthy fish

$\begin{array}{rr}0 & 0 / 6 \\ 160 & 0 / 6 \\ 1600 & 0 / 6 \\ 16000 & 5 / 6\end{array}$

¿im = intramuscular, $\mathrm{sc}=$ subcutaneous, $\mathrm{ip}=$ intraperitoneal, abr = bacteria applied to skin abraded with sandpaper

${ }^{\mathrm{b}}$ Reported as number of fish from which $B$. mycoides was isolated/number of fish challenged
The number of Bacillus mycoides required to produce muscle lesions in channel catfish appeared to be similar to that reported for $B$. cereus in mammals. Based on our preliminary data, $1.6 \times 10^{4} \mathrm{CFU}$ of $B$. mycoides im were required to produce lesions in channel catfish. Lethal doses of $B$. cereus in mice are $3 \times 10^{5}$ cells sc or $2 \times 10^{7}$ ip (Burdon et al. 1967). Interestingly, we have shown that as few as 130 CFU are sufficient to establish $B$. mycoides in lesions of fish that have been exposed to low concentrations of dissolved oxygen and that have concomitant infections with Aeromonas hydrophila complex.

The enrofloxacin used in our infectious-dose study enabled us to demonstrate that Bacillus mycoides infection was sufficient to cause muscle lesions, resembling those seen in the epizootic, without interaction with other pathogens. The use of enrofloxacin treatment may have caused us to overestimate the infectious dose because of inhibition of $B$. mycoides growth by antibiotic residue; however, inhibition of $B$. mycoides by enrofloxacin seems unlikely given the low infectious dose determined in this experiment

The source of the Bacillus mycoides in this epizootic is unknown. The ubiquitous nature of this bacillus makes both food-and water-borne transmission possible. No microbiological analysis was performed on samples of feed, sediment or water during the epizootic

The frequency of Bacillus mycoides infection in com- 
mercial aquaculture is difficult to determine. We attribute our success in isolating $B$. mycoides to the use of tissue explants instead of an inoculating loop. A loop may be unsuitable for sampling chains of $B$. mycoides that are tangled within tissues and present in low concentrations. It is also possible that, as is the case with mammals, $B$. mycoides isolates are regarded as contaminants and are therefore overlooked.

Acknowledgements. We thank Prof G. R. Wilt for his assistance in identifying Bacillus mycoides, and Prof. Joseph Kloepper and John McInroy for performing the gas chromatographic fatty acid analysis which confirmed our identification of the isolate. This work was partially funded by the Southeastern Cooperative Fish Disease Project.

\section{LITERATURE CITED}

Ansell, S. E., Lawton, E. B., McRae, S., Mortimer, G., Cursons, R. T. (1980). Endophthalmitis due to Bacillus cereus: case report. N.Z. med. J. 92: 12-13

Baya, A. M., Li, T., Lupiani, B., Hetrick, F. (1992). Bacillus cereus, a pathogen for striped bass. Eastern Fish Health and American Fisheries Society Fish Health Section Workshop, 16-19 June 1992, Auburn University, Auburn, A.L, p. 67

Baya, A. M., Toranzo, A. E., Lupiani, B., Li, T., Roberson, B. S., Hetrick. F. M. (1991) Biochemical and serological characterization of Carnobacterium spp. isolated from farmed and natural populations of striped bass and catfish. Appl. environ. Microbiol. 57: $3114-3120$

Bonventre, P. F., Eckert, N. J. (1963). The biologic activities of Bacillus cereus culture filtrates. Am. J. Pathol 43: 201-211

Burdon, K. L., Davis, J. S., Wende, R. D. (1967). Experimental infection of mice with Bacillus cereus: studies of pathogenesis and pathologic changes. J. infect. Dis. 117: $307-316$

Burr, E. W. (1981). Intranasal caseous fibrinous plug causing

Responsible Subject Editor: T Evelyn, Nanaimo, B.C. Canada upper respiratory distress in two African grey parrots (Psittacus erithacus). Avian Dis. 25: 542-544

Clark, G. (1981). Staining procedures. Williams and Wilkins, Baltimore

Claus, D., Berkeley, R. C. W. (1986). Genus Bacillus Cohn 1872, 174. In: Sneath, P. H. A. (ed.) Bergey's manual of systematic bacteriology, Vol. 2. Williams and Wilkins, Baltimore, p. 1105-1139

Gibson, T., Gordon, R. E. (1974). Genus Bacillus Cohn 1872 , 174. In: Buchanan, R. E., Gibbons, N. E. (eds.) Bergey's manual of systematic bacteriology, 8th edn. Williams \& Wilkins, Baltimore, p. 529-550

Gilbert, R. J., Kramer, J. M. (1984). Bacillus cereus enterotoxins: present status. Biochem. Soc. Trans. 12: 198-200

Harmon, S. M. (1982). New method for differentiating members of the Bacillus cereus group: collaborative study. J. Assoc. off. anal. Chem. 65: 1134-1139

Jack, S. W., Taylor, P. W., Crosby; M. D., Freund, J., MacMillan, J. R., Durborow, R. M. (1992). Summary of bacterial isolates from farm-reared channel catfish (1979-1988). J. Vet. Diagn. Invest. 4: 193-195

Kloepper, J. W., Mclnroy, J. A., Bowen, K. L. (1992). Comparative identification by fatty acid analysis of soil, rhizosphere, and geocarposphere bacteria of peanut (Arachis hypogaea L.). Plant Soil 139: 85-90

Parry, J. M., Turnbull, P. C. B., Gibson, J. R. (1983). A colour atlas of Bacillus species. Wolfe Medical Publications Ltd, London

Phillips, 1. (chairman) (1991). A guide to sensitivity testing. J. Antimicrob. Chemother. 27 (Suppl. D): 1-50

Pychynski, T., Malanowska, T., Kozlowski, M. (1981). Bacterial flora in branchionecrosis of carp (particularly Bacillus cereus and Bacillus subtilis). Med. Weter. 37 $742-743$ (in Polish, summaries in English and Rus$\operatorname{sian)}$

Sneath, P. H. A. (1986). Endospore-forming gram-positive rods and cocci. In: Sneath, P. H. A. (ed.) Bergey's manual of systematic bacteriology, Vol. 2. Williams and Wilkins, Baltimore, p. 1104-1105

Thune, R. L. (1991). Major infectious and parasitic diseases of channel catfish. Vet. Hum. Toxicol, 33 (Suppl. 1): 14-18

Manuscript first received: February 24, 1993

Revised version accepted: November 2, 1993 